\title{
Collection Development at the Center for Research Libraries: Policy and Practice
}

\section{Sarah E. Thomas}

One of the goals of the Center for Research Libraries' (CRL) collection development policy is the acquisition of materials not widely held by research libraries in North America. Despite the goal, this study finds that a significant number of serials currently received by CRL are also held by twenty or more libraries, as indicated by holding symbols on OCLC and RLIN. Both $C R L$ and its members stand to realize substantial savings through a cooperative policy of cancellation of duplicate holdings.

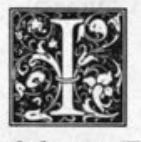

$\mathrm{n}$ recent months the mission and goals of the Center for Research Libraries (CRL) have been the subject of considerable debate. The Journal of Academic Librarianship, in its November 1983 issue, published varying perspectives on the Center as expressed by several leading professionals in the field. One of the topics of prime concern was its collection development policy. Should the Center collect comprehensively in some areas or selectively in many? Should CRL assume the role of the National Periodicals Center? Many of the Center's members were particularly interested in its journal holdings for purposes of document delivery; others felt their membership assessments should not subsidize this activity.

CRL's journals collection has evolved out of its programs and some special projects. A National Science Foundation grant enabled CRL to acid subscriptions to journals indexed in Chemical Abstracts and Bio- logical Abstracts that were infrequently held in North American libraries. Foreign titles from the P.L. 480 programs make up a substantial portion of the collection. During the economic woes of the early 1970 s, funds from the Carnegie Corporation supported the acquisition of titles at CRL that members were forced to cancel locally. ${ }^{1}$ The collection development and document delivery functions at CRL were linked together through the Journals Access Service, established by CRL membership in 1975.

In November 1983, CRL issued a policy discussion document that detailed its collection development policy. The document describes the Center's commitment to collecting certain types of material and certain subjects. For example, an effort was made to acquire ethnic newspapers issued in the United States as well as microfilm editions of domestic, generalcirculation newspapers. Microfilm editions of selected foreign newspapers,

Sarah E. Thomas is chief in the technical services division of the National Agricultural Library, Beltsville, Maryland 20705. The research supporting this paper grew out of a preliminary investigation conducted while the author was a Council on Library Resources academic library management intern at the University of Georgia Libraries during 1983-84. A Council on Library Resources officers' grant funded a revised version of the study. I am indebted to the Council for its support. In addition, David Bishop, Director, University of Georgia Libraries, provided the initiative for the research, as well as material and technical assistance. Thanks are also owed to Jim Scanlon, department manager, Office of Computing Activities, University of Georgia, for producing-from $C R L$ 's archives tapes-the lists of titles in each language that formed the basis of the study. Finally, I am grateful to the Research Libraries Group for their support in providing access to the RLIN database. 
primarily those covered by the P.L. 480 program, are also collected. In a general policy statement about periodicals, the document specifies that "The Center maintains subscriptions to all periodical titles that have been ordered under special programs and projects approved by the Council. Special emphasis is upon foreign titles in the fields of science and technology, and upon titles from South and Southeast Asia acquired through the Library of Congress' [sic] cooperative acquisitions programs for those areas. ${ }^{\prime 2}$ In addition, new subscriptions were entered in 1983 for "foreign titles that have been frequently requested through the Center's Journal Access Service and are not widely held in North America." ${ }^{\prime 3}$

Two principal guidelines characterize the Center's collection development policy with regard to serials. The first is to acquire materials relating to a specific subject or specific world area. Concentration on particular subjects enables the Center to assume collecting responsibility in these areas, thus providing its membership with centralized access to them, and allowing members to dispense with their own subscriptions if desired. A second, recurring theme in the document is that material acquired by the Center should supplement, rather than duplicate, major collections in the nation. These two criteria can operate in conflict; that is, periodical materials purchased in support of a particular program may duplicate holdings in other North American libraries, but in general, CRL's serial holdings have been viewed as complementing those of its members.

This paper explores the extent to which CRL's serial holdings are unique. If, as many Center members feel, the most effective use of the Center can be made if it serves as repository for and collector of unique items, there should be little overlap between the Center's holdings and those of other libraries. Acquisition and processing of a serial title by the Center can save many libraries subscription and processing costs, providing all CRL members the benefit of access to the title, while shaving expenditures for individual libraries. A few large research libraries may choose to duplicate certain titles held by the Center on a selective basis, but the general premise that CRL's serial holdings should be complementary to, but distinct from, those of its membership should remain valid.

\section{METHODOLOGY}

CRL holds an estimated 50,000 current and retrospective serial titles. ${ }^{4}$ Approximately 13,500 are currently received. ${ }^{5}$ By spring $1984,15,389$ serials had been cataloged in machine-readable form. This study concentrates primarily on those titles available in machine-readable form and coded as currently received by CRL. Just under half, or 48.46 percent of these 15,389 serial titles, are estimated to fall in this category.

In a study conducted at the University of Georgia in June 1984, various subsets of the Center's cataloged serial holdings were surveyed to determine the number of locations that reported holding the same title as cataloged by the Center. Records in five languages-English, German, Japanese, Russian, and Urdu-were searched in the OCLC and RLIN databases. These languages represent four major linguistic areas in which the Center collects materials. In addition, with the exception of Urdu, they represent four of the five most widely-held languages in the Center's journal collection. Combined, they comprise almost two-thirds of the Center's 15,389 cataloged serials in machine-readable form.

OCLC and RLIN were selected as the online catalogs serving as de facto equivalents of the National Union Catalog. Although printed sources such as the $\mathrm{Na}$ tional Union Catalog, the Union List of Serials, and New Serial Titles provide location information that is not always available online, particularly for retrospective titles, the researcher viewed OCLC and RLIN as prime sources of information for those seeking a location for a title not found in their own library. Because most major research institutions are now affiliated with a network providing access to online bibliographic data, almost all current periodical titles and a substantial number of retrospective titles are now 
available online. Also, the large OCLC and RLIN databases provide facile access to material, reducing the need to rely on tedious, cumbersome manual searching of published sources. Of course, details of holdings may not be identical in all libraries. Until a format for representing detailed holdings is implemented nationwide, and until all libraries have input this information, the exact amount of duplication of serial holdings cannot be known with certainty.

English, German, Japanese, Russian, and Urdu serial titles comprise 10,802 records entered into the OCLC database by CRL. Using Blackwell North America software, computer-center staff at the University of Georgia produced a list for each language, arranged in descending order by OCLC number. Approximately 10 percent of the records in each language, or a total of 1,069 titles, were selected to be searched on OCLC and RLIN. For each periodical title searched, the number of locations holding the title was noted. Because of tape loading of records from those libraries that have been members of both networks, there was some slight overlap between the two databases. However, the duplication did not significantly affect the results, because the data collected was divided into ranges of numbers broad enough to negate any redundancy.

No attempt was made to determine whether or not holding libraries were CRL members. In addition, the searcher recorded the publication status of the item being searched. Publication status was either "current," for titles still being issued at the time CRL cataloged the title on OCLC, or "other," including "dead" serials no longer published, serials for which publication had been suspended, and serials with an unknown publication status. This study focused principally on currently received serials, of which the sample contained 518 titles.

\section{RESULTS}

The results varied considerably according to the language of the piece. Among the current Urdu language titles, for example, 70.59 percent were held exclusively by the Center (See table 1). Of the Japanese titles searched, almost 43 per-

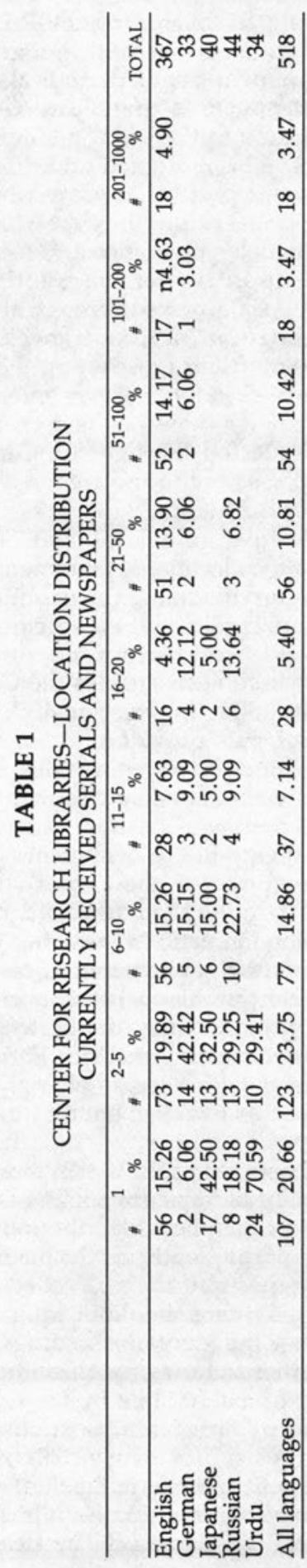


cent listed CRL as the sole location. Approximately 20 percent of the Russian periodicals were unique to $C R L$, while about 16 percent of the English titles were attributed to the Center only. The lowest percentage of current titles was for German language materials, with 6.06 percent uniquely held. According to this sample, 20.66 percent of titles held by CRL in these five languages were unique to $C R L$.

A slightly greater percentage, 23.75 percent of all current titles sampled, were found to be held by two to five libraries in North America, including CRL. For German-language periodicals, 42.42 percent fell into this category. Englishlanguage serials represented the lowest percentage of uncommon serials, with 19.89 percent listing more than one but fewer than six locations. Once again, the least amount of duplication among North American libraries was noted in foreign language publications.

Fewer titles had six to ten locations. CRL shared around 15 percent of its current cataloged serial holdings with five to nine other libraries. Most of these titles were in English. Of the Center's cataloged periodicals, 7.14 percent listed more than ten and up to twenty locations. Altogether, an estimated two-thirds of the Center's current periodicals collection was held by fewer than twenty libraries. The remaining third had been cataloged by from 21 to 998 libraries, with the relative amount of duplication dropping off sharply after fifty locations. For example, slightly fewer than 3.5 percent of the current titles were held by more than two hundred libraries.

The results of this study indicate that, for the most part, CRL is adhering to its collection development policy of limiting its subscriptions primarily to periodical literature not widely held in North America. If one accepts a definition of "rarely held" as being five or fewer libraries, an estimated 44.41 percent of the Center's serials meet this criterion. If this definition is expanded to include fifteen or fewer locations, almost two-thirds of the current titles sampled fit this description. Excluding English-language materials, over 86 percent of the titles have been cataloged on OCLC or RLIN by fifteen or fewer libraries.
However, particularly in the area of English-language periodicals, some conflict with the Center's collection development policy is apparent. Over 35 percent of current English serials, cataloged by the Center on OCLC, are listed as being located at from 21 to several hundred institutions. While several popular titles are for professional magazines to which every research library would subscribe, such as American Libraries, Library Trends, or Information Technology and Libraries, many others are not. For example, in 1982 the Center initiated a subscription for the Journal of Divorce, a quarterly that over 150 other institutions hold. No doubt in accordance with its policy of collecting publications issued in South and Southeast Asia, the Center holds Cinema Vision India, listed as being in 83 other OCLC libraries and found in 12 RLIN libraries. Geochimica et cosmochimica acta, published by Pergamon Press at a price of $\$ 100$ per institutional subscription, is a scientific journal that falls within the scope of CRL's collection in terms of subject definition but is widely held, with almost 200 libraries claiming ownership on OCLC and RLIN. Interdisciplinary Topics in Gerontology (93 libraries); Byzantine Studies (69 libraries); Applied Ergonomics (91 libraries); and Family Therapy (98 libraries) are but a few examples of CRL titles held by multiple institutions. Such titles are now at variance with the Center's 1983 collection development policy of acquiring items rarely found in North American libraries and are evidence of the conflict between its role as document deliverer through its Journal Access Service and its commitment to develop its collection in particular subject areas. CRL's Journal Access Service (JAS), initiated in 1975, brought it into the journal supply business, with some members perceiving document delivery as a prime attraction. Other members make little use of JAS and are not certain whether the best use of their membership assessments is in the support of this program. ${ }^{6}$ They view CRL's chief value in terms of its overall collection and the unique materials it preserves in a centralized location.?

It is precisely this gray area of widely held serials that points up CRL's dilemma. If resources were unlimited, it is 
possible the acquisition of more commonly held journals would pass unquestioned, and the Center could quietly develop into a centralized facility with many of the attributes of the proposed National Periodicals Center. However, because many libraries continue to operate in a period of economic retrenchment, they have examined all their commitments with care. An outgrowth of this scrutiny has been a reevaluation of the Center's goals. Two steps to resolve the dilemma, each of which would strengthen the Center's role in the research library community, present themselves. First, the Center could cancel subscriptions for most serials held by over twenty libraries. Secondly, CRL members could review subscriptions to infrequently used periodicals to determine if it might not be preferable, from a cost standpoint, to rely on the Center for these titles, rather than to maintain them locally.

Evidence suggests that over 28 percent of titles currently received and cataloged by CRL, using OCLC, are held by twenty or more libraries. If even half of these could be eliminated, the Center could reduce current periodicals subscriptions by over 1,000 . Applying the average cost of a domestic serial as $\$ 78.04,{ }^{8}$ a savings of as much as $\$ 78,040$ could be attained. This represents approximately 29 percent of the 1984 budget for serials, ${ }^{9}$ assuming that duplicate journals were paid subscriptions, and not received as gifts or exchanges.

The second step is for CRL members to cut subscriptions locally. Many members perceive the Center's greatest benefit to them in terms of cost-avoidance. When the Center purchases titles, libraries can obtain journal issues through $\mathrm{CRL}$, rather than resorting to the costly measure of acquiring, processing, and shelving infrequently used material locally. Libraries cooperating with CRL in a collection development effort should look to reducing their holdings of serials rarely used at their own institutions. These might be foreign-language materials or even English-language periodicals on specialized subjects that are not central to the institutions' teaching and research areas. In 1984, CRL had over 140 full members. If each of these institutions found that it could eliminate 50 periodical subscriptions from its orders, each would reduce its expenditures for serials by approximately $\$ 4,000 .^{10}$ Eliminating the cost of processing, storage, and binding would double the savings.

As a case in point, this study also examined the overlap of the University of Georgia Libraries' collection with that of CRL. Searching 1,069 titles on OCLC, the investigation found 98 , or 9.17 percent, titles were also held by the University of Georgia. Most of these titles were in English. Not all retrospective titles held by the university libraries are listed in OCLC. Comparing titles no longer published with entries in the Georgia libraries' serials catalog suggests that an additional 10 percent of "dead" periodicals may be duplicated in the Center's collection. Because the university libraries have converted almost all their currently received serials to machine-readable form using OCLC, the most accurate comparison of overlap is between the libraries' current titles and current titles at CRL. Overall, 16.03 percent of the current CRL serial titles searched were also held by the university libraries. Over 20 percent of the currently cataloged English-language titles were duplicates. A study of German-language duplicates at the University of Georgia, conducted by the author in March 1984, indicated that approximately 23 percent were candidates for elimination. If only 10 percent of the serial titles also owned by CRL were canceled, the Georgia libraries could save $\$ 5,429.12$ in materials expenditures. Sixty-eight titles, which cost an average $\$ 79.64$ each, could be cut. ${ }^{11}$ Perhaps an additional $\$ 5,000$ in processing, binding, and shelving costs could be realized. The figure above represents approximately half of Georgia's membership assessment by CRL.

It is assumed that other institutions would reap similar benefits, although local studies would need to be conducted to test this assumption. The fact remains, however, that one of the fundamental principles underlying CRL's existence is that of shared collection development. In the past, CRL's well-being has been troubled by splintered collection development 
policies that fragmented its resources and clouded its image in the library community. Endeavoring to meet the varying needs of its membership, the Center spread its purchases widely, falling prey to the pitfall of trying to be all things to all people. CRL's strength lies in its ability to collect materials in specialized subjects or world areas that are not commonly held by its members.

Recognizing that its identity and role among libraries requires clarification, the Center has invited discussion on the nature of its periodical holdings and its collection development policy in this area. Focus on the Center for Research Libraries recently announced that "For many years the Center's Council has expressed the opinion that CRL could serve the membership by expanding its periodical holdings-relieving members of an increasing financial burden. Agreement has been reached that in the future CRL's periodical collection should focus on titles published outside of the United States, the United Kingdom, and Canada; and that titles be held by a limited number of North American libraries."

\section{CONCLUSION}

Only through a well-defined, consistent collection development policy and the cooperative efforts of its membership can CRL fulfill its mission "to strengthen the library and information resources for research in North America and to enhance the availability to those resources. ${ }^{\prime 13}$ To achieve this end, the Center needs to reduce the extent of overlap from its collection to the holdings of its members and to concentrate on those items that complement its members' collections. For the Center to succeed in its efforts, however, its members must support policy decisions that have occurred through consensus. In addition, they must use the Center more effectively, relying on its centralized facilities and collections in lieu of offering direct, local access to infrequently used titles. Furthermore, they must publicize the Center's capacity, integrating the record of the Center's holdings with their own collection so that patrons, in effect, regard the Center as an extension of their own institution. When research libraries and the Center work together toward a common goal-sharing development, management, and content of collections-they bring renewed vigor to the nation's libraries and the scholarly community they serve and also fulfill the mission they envision for CRL.

\section{REFERENCES AND NOTES}

1. Donald B. Simpson, "Center for Research Libraries: Meeting the Opportunity to Fulfill the Promise: a Symposium," Journal of Academic Librarianship 9:258-69 (Nov. 1983).

2. "The Center for Research Libraries: Collection Development Policy," Chicago: Center for Research Libraries, 1983, p.14.

3. Ibid.

4. "HEA Title II-C Grant Awarded for Records Conversion," Focus on the Center for Research Libraries 4:1 (May-June 1984).

5. "The Center for Research Libraries: Collection Development Policy," p.16.

6. Simpson, "Center for Research Libraries," p.259.

7. Ibid.

8. The Bowker Annual of Library and Book Trade Information. 29th ed., India Ehresman, comp. and ed. (New York: Bowker, 1984), p.392.

9. "The Center of Research Libraries: Collection Development Policy," p.16.

10. The 'University of Georgia has recently calculated that its average cost for domestic and foreign periodicals is $\$ 79.64$ per title. This figure was applied for purposes of estimation.

11. Ibid.

12. "Current Discussion Issues Related to CRL Program." Focus on the Center for Research Libraries, 4:2 (May-June 1984).

13. Simpson, "Center for Research Libraries," p.261. 